\title{
PERAN RUANG PUBLIK PADA KANTOR RUKUN WARGA TERHADAP AKTIVITAS MASYARAKAT DI KELURAHAN KEBON PALA JAKARTA TIMUR
}

\author{
Dedi Hantono ${ }^{1,}$ Noer Aziza ${ }^{2}$ \\ ${ }^{1}$ Universitas Muhammadiyah Jakarta, email: dedihantono@umj.ac.id \\ ${ }^{2}$ Badan Kependudukan dan Keluarga Berencana Nasional, email: noeraziza@bkkbn.go.id
}

\begin{abstract}
Jakarta is one of the big cities in Indonesia which has a high population density. The impact of this is the limited public space needed by the community for activities, such as: social, refreshing, sports, and others. Rukun Warga as part of a government institution that is public service and has its own operational office building should also be enjoyed by all levels of society. However, if you pay attention to the $R W$ office, it still looks deserted from daily community activities. For this reason, a research was conducted on the causes of the lack of functioning of the RW office as a public building. How can this happen. The method used in this study used a descriptive qualitative approach. From the research conducted, it is known that there are several factors, including: inadequate space dimensions, closed offices, and unkempt open spaces and even switching functions.
\end{abstract}

Keywords: Public Space, Activities, Citizen Association, Government Agencies, Public Services

\begin{abstract}
Abstrak
Jakarta merupakan salah satu kota besar di Indonesia yang memiliki tingkat kepadatan penduduk yang cukup tinggi. Dampak dari hal tersebut adalah semakin terbatasnya ruang publik yang dibutuhkan masyarakat untuk beraktivitas, seperti: sosial, refreshing, olahraga, dan lain-lain. Rukun Warga sebagai bagian dari lembaga pemerintah yang bersifat pelayanan publik dan memiliki bangunan kantor operasional sendiri sudah selayaknya juga dapat dinikmati oleh seluruh lapisan masyarakat. Namun jika diperhatikan kantor RW masih terlihat sepi dari aktivitas masyakarat sehari-hari. Untuk itu dilakukan penelitian penyebab kurang berfungsinya kantor RW sebagai bangunan publik. Bagaimana hal tersebut dapat terjadi. Metode yang digunakan dalam penelitian ini menggunakan pendekatan kualitatif deskriptif. Dari penelitian yang dilakukan diketahui ada beberapa faktor penyebab, diantaranya: dimensi ruang yang kurang memadai, kantor yang tertutup, dan ruang terbuka yang tidak terawatt bahkan beralih fungsi.
\end{abstract}

Kata-kunci : ruang publik, aktivitas, rukun warga, lembaga pemerintah, pelayanan publik

\section{Pendahuluan}

Sebagai kota besar, Jakarta memiliki tingkat kepadatan penduduk yang cukup tinggi dengan wilayah yang tidak begitu luas dibandingkan dengan daerah lain di Indonesia Angka ini cukup menjadi indikator betapa terbatasnya sarana dan prasarana yang tersedia. Pemukiman yang padat menimbulkan persaingan dan harga lahan yang melonjak tinggi sehingga hampir tidak terjangkau oleh sebagian masyarakat (Setyowati, Djunaedi, Pramitasari, \& Sarwadi, 2020). Faktor nilai harga yang tidak terjangkau menjadikan mereka menempati rumah yang sederhana (Silitonga \& Naibaho, 2019). Dampak lainnya adalah ruang publik yang tersedia tidak sebanding jumlahnya. Penduduk kota yang berada dalam pemukiman padat seperti ini biasanya memiliki sifat guyup yang cukup kental (Prayitno, 2017). Oleh karena itu sangat dibutuhkan ruang publik sebagai wadah bagi nilai keguyupan kehidupan masyarakat berdasarkan nilai gotong royong dan kekeluargaan. Dalam kehidupan sehari-hari nilai-nilai kekeluargaan tersebut dapat dalam bentuk aktivitas sosial, olahraga, refreshing, dan lain-lain.

Dampak dari ruang publik yang terbatas akan dikhawatirkan akan mengganggu kualitas hidup masyarakat. Apalagi setiap masyarkat berhak akan ruang pribadi maupun ruang publik untuk kehidupan sosialnya sesuai dengan UU No.52 tahun 2009 tentang Perkembangan Kependudukan dan Pembangunan Keluarga pasal 5 ayat (p) yang menyatakan bahwa penduduk berhak memperoleh dan mempertahankan ruang hidupnya. Sejalan dengan hal tersebut pemerintah 
membangun lembaga kerukunan bagi warganya yang disebut Rukun Warga (RW). Rukun Warga memiliki peran yang sangat strategis sebagai mitra pemerintah dalam urusan pemerintahan, pembangunan, dan kemasyarakatan. Salah satu contoh bentuk kemitraan tersebut adalah pendidikan anak usia dini, pos pelayanan kesehatan terpadu, rapat warga, dan lain-lain. Lembaga ini berada langsung dalam koordinasi lembaga kelurahan dan masing-masing RW memiliki kantor operasional sendiri (Hastona, 2015).

Kepublisitasan ruang publik menjadikan ruang ini dapat diakses oleh siapa saja untuk melakukan aktivitas tertentu (Madanipour, 2003). Rukun Warga (RW) sebagai lembaga masyarakat yang berfungsi untuk melayani masyarakat umum menjadikan kantor RW sebagai bangunan publik sehingga bisa diakses oleh siapa saja terutama oleh warga yang berada dalam kawasan RW yang sama. Melihat fenomena ini seharusnya kantor RW yang bersifat publik ini bisa dimanfaatkan warganya untuk memenuhi kebutuhan setiap anggota keluarga yang bermukim di sekitar kantor tersebut. Namun bila dilihat sepintas, keberadaan kantor ini tidak berfungsi dengan baik. Kantorkantor ini terlihat sepi terutama kantor RW yang berada di Kelurahan Kebon Pala Jakarta Timur.

Untuk itu perlu dilakukan penelitian mengenai sejauh mana kantor RW ini dirasakan manfaatnya bagi warganya. Apakah berfungsi dengan baik sesuai dengan sifat publisitasnya? Dan bagaimana hal ini dapat terjadi?.

\section{Tinjauan Pustaka}

\section{Aktivitas pada Ruang Publik}

Makna aktivitas pada suatu ruang (Gehl, 1987) dapat dibagi menjadi tiga macam kegiatan, yaitu:

1. Aktivitas utama (necessary activities), yaitu kegiatan rutin yang dilakukan karena keharusan untuk memenuhi suatu kebutuhan tertentu. Lingkungan yang baik adalah lingkungan yang dapat menampung dan mewadahi semua jenis kegiatan yang dibutuhkan.

2. Aktivitas pilihan (optional activities), yaitu kegiatan yang dilakukan ketika ada kesempatan atau waktu yang tepat. Biasanya kegiatan ini dilakukan pada situasi lingkungan yang cukup menyenangkan dan tidak adanya aktivitas lain yang lebih mendesak.

3. Aktivitas sosial (social activities), yaitu kegiatan yang melibatkan interaksi dengan pihak lain disekitarnya. Kegiatan ini cenderung tidak terencana dalam pelaksanaannya karena adanya aktivitas utama dan aktivitas pilihan.

Dari ketiga aktivitas tersebut maka aktivitas pilihan dan sosial lebih banyak dilakukan dalam ruang publik. Aktivitas sosial yang menjadi bagian dari sistem sosial merupakan aktivitas interaksi yang dilakukan dengan orang lain pada pola kelakuan tertentu (Jodie, Silitonga, \& Aritonang, 2019).

Pola aktivitas dan pola pemanfaatan ruang dapat diketahui dengan mengamati aktivitas dan pergerakannya (Hantono, 2017). Kedua pola ini adalah bagian dari aspek yang akan dikaji dalam melakukan analisis terhadap behavior setting. Analisa behavior setting dilakukan dengan menggunakan beberapa kriteria sebagai berikut:

1. Pelaku kegiatan (person).

2. Pola prilaku (standing pattern of behavior), yaitu: aktivitas yang berulang-ulang pada setting tertentu.

3. Batasan fisik ( $p h y s i c a l$ milieu).

4. Hubungan antara batasan dan pola aktivitas (tynomorphyc).

5. Wilayah kuasa (territory).

6. Waktu tertentu pada saat aktivitas berlangsung (temporal).

Kegiatan yang dilakukan oleh seseorang atau sekelompok orang pada suatu lingkungan dapat diamati pada waktu-waktu tertentu, serta tidak dapat lepas dari wilayah atau ruang aktivitasnya (Lang, 1987). Dalam hal tersebut ada 6 aspek yang harus diperhatikan dalam memahami pola prilaku yang timbul, yaitu: pengguna, kegiatan, jumlah pengguna, wadah, posisi, dan waktu.

Shirvani menjelaskan bahwa pendukung aktivitas cukup dekat kaitannya dengan fungsi dan tata guna lahan yang dapat memperkuat ruang kota dari segi aktivitas. Bentuk fisik tersebut meliputi fungsi dominan seperti taman rekreasi, pusat kebudayaan, pusat perbelanjaan, pelayanan jasa, museum, perpustakaan, dan lain-lain. Sektor informal termasuk dalam kategori pendukung aktivitas, seperti: pedagang kaki lima, pangkalan becak, dan lain-lain (Shirvani, 1985). Perilaku pengguna ruang publik terdapat dipengaruhi oleh beberapa faktor penggunaan ruang terbuka, 
diantaranya: tempat duduk, sinar matahari, angin, vegetasi, air, makanan, akses fisik dan visual langsung ke jalan utama, dan lain-lain (Hantono \& Hakim, 2019).

Penelitian-penelitian yang pernah dilakukan sebelumnya menunjukkan bahwa perancangan ruang yang tidak didasarkan pada standing pattern of behavior rawan terhadap timbulnya konflik ruang (Soegiono dalam Santoso, 2016). Konflik ini akan terjadi pada ruang yang mewadahi beberapa fungsi dengan berbagai karakter kegiatan yang berbeda. Penataan ruang yang disusun berdasarkan pola aktivitas utama dapat efektif dalam memanfaatkan keterbatasan ruang yang ada. Hal ini disebabkan kegiatan utama pada umumnya mendominasi penggunaan ruang sehingga pengguna ruang lain harus menunggu untuk mendapatkan giliran kemudian (Santoso, Mustikawati, Suryasari, \& Titisari, 2016).

Sedangkan menurut Rustam Hakim bahwa ruang adalah suatu wadah yang tidak nyata namun bisa dirasakan keberadaanya. Hal rasa ini bisa didapat dari panca indera yang dimiliki oleh manusia yang fungsinya memang untuk merasakan sesuatu hal. Ruang bisa terlihat secara kasat mata wujudnya. Ruang juga bisa terasa oleh sentuhan-sentuhan halus pada kulit manusia. Ruang juga memiliki aroma pada satu rasa yang sama. Rustam Hakim menyorot ruang sebagai keberadaan yang dapat dirasakan baik secara fisik maupun dengan menggunakan panca indera yang dimiliki manusia (Hakim \& Utomo, 2003).

Bila dikutip dari ahli yang berasal dari luar, ruang publik adalah suatu tempat dimana terjadinya kehidupan secara bersama (Carr, 1992). Tentu aktivitas yang terjadi dalam ruang publik dilakukan secara bersama walaupun bisa dalam waktu dan tujuan yang berbeda. Jalan, lapangan, dan taman kota ikut memberi bentuk dari pasang surutnya kehidupan manusia yang dinamis (Carr, Francis, Rivlin, \& Stone, 1992).

Sedangkan Rob Krier (1979) mengartikan sebagai ruang yang berada diantara bangunanbangunan perkotaan maupun daerah. Krier lebih detail menjelaskan secara fisik bahwa ruang publik merupakan ruang yang terbentuk antar massa bangunan (Krier, 1979). Sehingga pendapat ini hampir sama dengan Eko Budihardjo yang menyebutkan bahwa ruang publik adalah ruang yang berada di luar bangunan atau berada pada ruang terbuka. Krier lebih senang menyebut ruang publik sebagai ruang kota.

Dari beberapa pengertian yang diajukan oleh beberapa ahli maka dapat disimpulkan bahwa ruang terbuka publik adalah ruang terbuka yang berada di luar bangunan yang dapat dipergunakan oleh manusia, baik secara individu maupun berkelompok untuk melakukan aktivitas sehari-hari, seperti: berjalan, berolah-raga, rekreasi, sosialisasi, dan lain-lain.

Ruang publik menurut Rob Krier (1979) ada 2 bentuk, yaitu:

1. Memanjang (the street), yaitu ruang yang memiliki dimensi lebih panjang pada kedua sisinya dibandingkan sisi lainnya. Ruang yang berbentuk seperti ini memiliki kecenderungan membentuk pola sirkulasi linear, satu arah, sejajar. Pada umumnya ruang publik yang memiliki bentuk seperti ini adalah jalan, sungai, koridor, dan lain-lain.

2. Persegi (the square), yaitu ruang yang memiliki dimensi yang hampir sama pada seluruh sisinya, memiliki kecenderungan membentuk pola sirkulasi ke segala arah, acak, organik. Pada umumnya ruang publik seperti ini dalam wujud lapangan, taman, dan lain-lain.

Secara karakteristik, geometris keduanya memiliki bentuk yang sama namun yang membedakan adalah pola fungsi dan sirkulasinya.

Rustam Hakim berpendapat bahwa berdasarkan keberadaannya maka ruang publik memiliki 2 (dua) golongan, yaitu:

1. Ruang publik tertutup, yaitu ruang publik yang terdapat di dalam bangunan atau halaman suatu bangunan/gedung. Ruang ini biasanya bisa diakses oleh banyak orang namun dalam batasan tertentu.

2. Ruang publik terbuka, yaitu ruang publik yang berada di luar bangunan. Ruang publik ini lebih jamak diakses oleh banyak orang.

Ruang publik memiliki 2 (dua) fungsi utama, yaitu:

1. Fungsi sosial, memiki fungsi sebagai wadah aktivitas manusia, diantaranya:
a. Sebagai tempat bermain dan berolah raga.
b. Sebagai tempat bermain dan sarana olahraga.
c. Sebagai tempat komunikasi sosial.
d. Sebagai tempat peralihan dan menunggu. 
e. Sebagai tempat untuk mendapatkan udara segar.

f. Sebagai sarana penghubung antara satu tempat ke tempat lainnya.

g. Sebagai pembatas antar massa bangunan.

h. Sebagai sarana penelitian dan pendidikan serta penyuluhan bagi masyarakat untuk membentuk kesadaran lingkungan.

i. Sebagai sarana untuk menciptakan kebersihan, kesehatan, keserasian, dan keindahan lingkungan.

2. Fungsi ekologis, lebih dekat keterkaitannya dengan alam, diantaranya:

a. Sebagai penyegar udara, mempengaruhi dan memperbaiki iklim mikro.

b. Sebagai penyerap air hujan.

c. Sebagai pengendali banjir dan pengatur tata air.

d. Sebagai pemelihara ekosistem tertentu dan perlindungan plasma nutfah.

e. Sebagai pelembut arsitektur bangunan.

Ruang publik juga dapat berfungsi sebagai:

1. Pusat interaksi dan komunikasi masyarakat baik formal (upacara bendera, Shalat Ied, bazaar, dan lain-lain), maupun informal (demonstrasi mahasiswa, pertemuan antar individu, dan lainlain.

2. Sebagai tempat kegiatan pedagang sektor non formal, seperti: pedagang makanan, souvenir, tambal ban, dan lain-lain.

3. Sebagai paru-paru kota sehingga banyak masyarakat yang memanfaatkan sebagai tempat berolahraga, bermain, rekreasi bersama keluarga, dan lain-lain.

\section{Metode Penelitian}

Pentingnya metode yang tepat dalam sebuah penelitian berdampak pada keakuratan hasil penelitian tersebut. Dan untuk mendapatkan metode yang tepat perlu disimpulkan terlebih dahulu mengenai rumusan masalah dan kajian yang literatur yang dibutuhkan.

Dalam melakukan penelitian ini, peneliti melewati bebeapa tahap penelitian, diantaranya:

1. Tahap persiapan.

Pada tahap awal ini peneliti melakukan beberapa persiapan, diantaranya:

a. Menyiapkan peralatan penelitian yang dibutuhkan, seperti: alat tulis, komputer, kamera, dan lain-lain.

b. Melaksanakan observasi awal untuk mendapatkan gambaran mengenai karakteristik lokasi yang akan diteliti. Observasi adalah metode pengumpulan data melalui pengamatan dengan menggunakan panca indera manusia. Pada tahap ini bisa langsung melakukan pengumpulan data atau hanya sekedar meninjau lokasi penelitian.

c. Menyusun kerangka penelitian untuk mengetahui data dan literatur yang diperlukan.

d. Menyusun hipotesa, variabel, dan lain-lain.

e. Menyiapkan daftar pertanyaan untuk wawancara jika diperlukan.

2. Tahap pengumpulan data.

Data adalah bahan keterangan tentang suatu obyek penelitian yang diperoleh di lokasi penelitian. Kekurangan bahan dan sumber data serta kesalahan dalam memilih data dapat mengakibatkan hasil penelitian yang kurang tepat dan tidak sesuai dengan yang diharapkan bahkan dapat menyesatkan para pembaca. Ada 3 macam data yang bisa diambil selama penelitian, diantaranya:

a. Data primer, berasal dari obyek penelitian secara langsung, seperti: lokasi dan obyek penelitian.

b. Data skunder, dibutuhkan dalam mencari teori-teori pendukung yang relevan dengan kasus penelitian. Dengan teori inilah maka hasil penelitian dapat dipertanggungjawab-kan.

c. Data tersier, merupakan kompilasi data primer dan skunder, seperti: katalog, angket. Angket adalah suatu metode pengumpulan data dalam bentuk rangkaian pertanyaan yang harus diisi oleh responden. Metode ini memiliki beberapa kelemahan, misalnya: hanya dapat dilakukan oleh responden yang bisa baca tulis, perlu ketelitian dalam menyusun pertanyaan yang bisa dipahami oleh seluruh lapisan responden, bisa terjadi kesalahan 
pengisian angket baik dikarenakan kesalahpahaman responden atau kesengajaan mereka serta dibutuhkan waktu ekstra untuk mensosialisasikan bahan angket serta proses dan pengumpulan hasil angket.

Atas dasar inilah peneliti tidak melakukan data angket karena keterbatasan waktu. Selain itu, untuk mencari suatu pola cukup dapat dilakukan dengan melakukan pengamatan dan kajian literatur.

3. Tahap analisis dan temuan, merupakan inti dari proses penelitian. Selain data yang telah dikumpulkan dengan lengkap maka pemilihan pendekatan dan metode yang tepat merupakan salah satu kunci keberhasilan suatu penelitian.

Menurut Lang (1987) penelitian yang dilakukan dengan pendekatan kualitatif dapat melalui pengamatan dan pemetaan perilaku (behavior mapping) untuk mengetahui pola aktivitas seseorang. Metode analisis deskriptif dilakukan untuk memperoleh pengunaan ruang berdasarkan pola aktivitas seseorang.

Untuk memperkaya penelitian tetap diperlukan wawancara langsung dengan pelaku untuk membantu penulis dalam melihat dan mendeskripsikan aktivitas yang berlangsung di dalam kawasan ini.

\section{Hasil dan Pembahasan}

\section{Deskripsi Lokasi}

Kelurahan Kebon Pala terletak di Kecamatan Makasar Kotamadya Jakarta Timur. Pada sisi Utara sebagian wilayahnya terpotong oleh ruas Jalan Tol Cikampek dan Cawang Interchange. Luas wilayah kelurahan ini mencapai 2,29 Km2 dengan jumlah penduduk sebesar 37.226 jiwa yang terdapat di dalam 7.401 Kepala Keluarga $(K K)^{1}$ per Desember 2008. Berdasarkan pembagian wilayah administrasi, kelurahan ini terdiri dari 137 Rukun Tetangga (RT) yang dibagi dalam 12 Rukun Warga (RW) sedangkan kantor Kelurahan Kebon Pala terletak di Jalan Jengki. Untuk penelitian ini diambil 4 sample kantor RW, yaitu: RW 04, RW05, RW 08, dan RW 09.

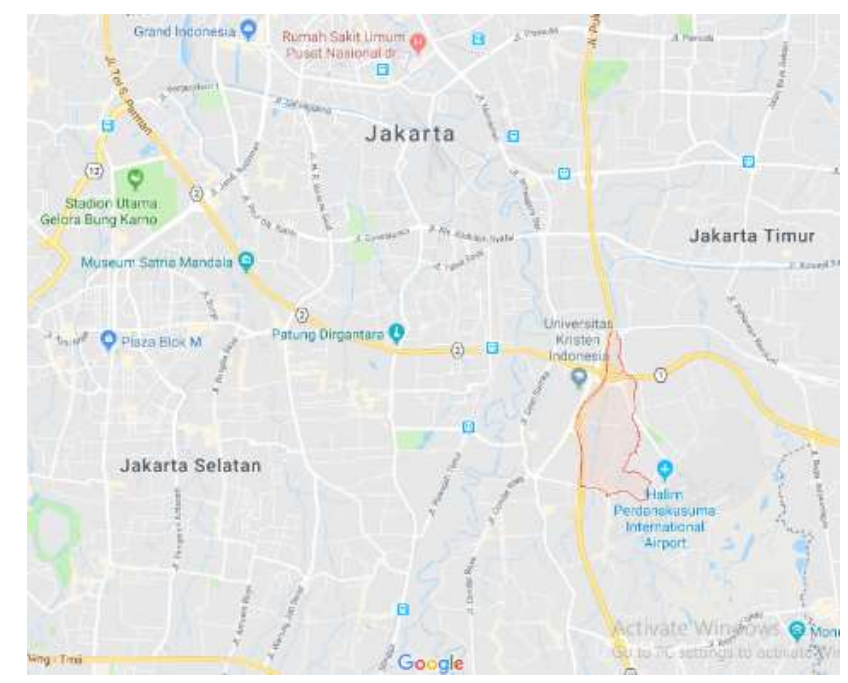

Gambar 1. Wilayah Kelurahan Kebon Pala, Jakarta Timur

\footnotetext{
${ }^{1}$ https://id.wikipedia.org/wiki/Kebon_Pala,_Makasar,_Jakarta_Timur 
Jurnal Arsitektur ALUR - Vol 3 No 2 September 2020

e-ISSN 2685-1490; p-ISSN 2615-1472

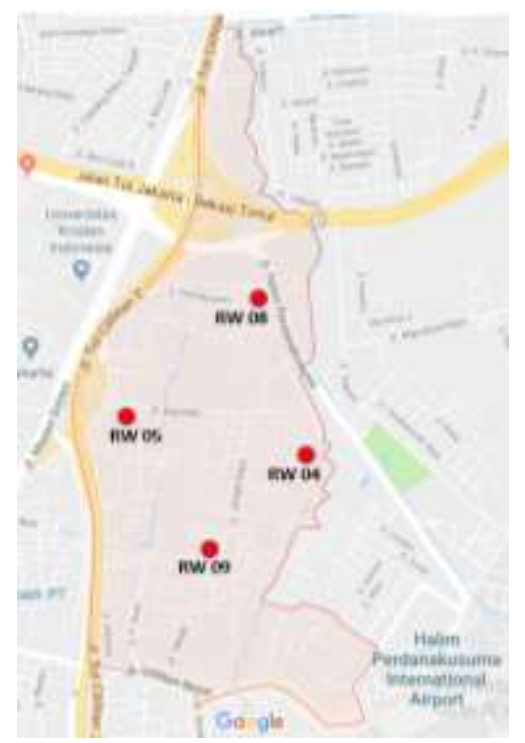

Gambar 2. Lokasi beberapa sample kantor RW di Kelurahan Kebon Pala

\section{Penggunaan Kantor RW 04}

Kantor RW 04 terletak di Jalan SD Inpres. Akses menuju kantor ini cukup sempit, hanya bisa dilalui 1 jalur kendaraan roda empat. Keberadaan kantornya sendiri pun cukup terpencil, di ujung jalan tersebut dan diapit oleh belakang tembok kantor Badan Kependudukan dan Keluarga Berencana Nasional (BKKBN) dan Sekolah Dasar Negeri (SDN) Kebon Pala 14 Pagi.
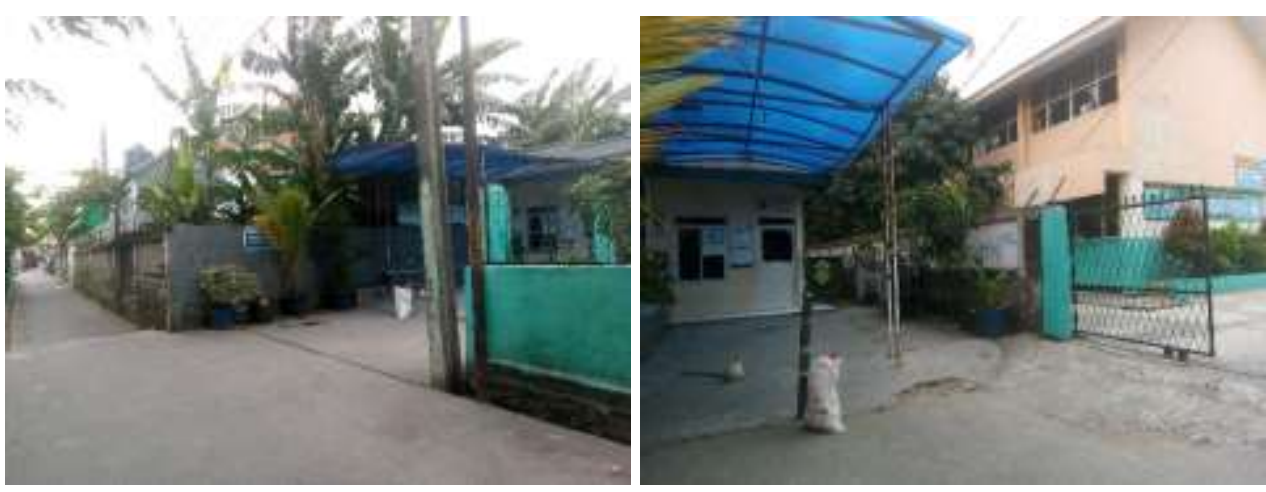

Gambar 3. Kantor RW 04

Kantor RW ini mulai beroperasional dari hari Senin sampai Jumat pada malam hari. Pada pagi sampai sore hari kantor ini tidak digunakan. Bangunan memiliki halaman yang tidak begitu luas dan tidak berpagar sehingga siapa saja dapat mengaksesnya. Oleh karena itu kantor ini sebenarnya memiliki potensial untuk digunakan kegiatan warga sekitarnya.

Kekosongan kantor ini dikarenakan kepala RW dan beberapa staf yang memiliki pekerjaan utama diluar dari kantor RW sehingga justru pada saat pagi hingga sore hari kantor ini tidak terlihat berfungsi sebagaimana kantor lazimnya.

\section{Penggunaan Kantor RW 05}

Kantor RW 05 terletak di Jalan Permata. Akses menuju kantor ini cukup mudah karena terletak pada jalan yang cukup lebar. Keberadaan kantor ini juga cukup mudah dikenali karena berada pada jalur lalu lintas warga. 
Jurnal Arsitektur ALUR - Vol 3 No 2 September 2020

e-ISSN 2685-1490; p-ISSN 2615-1472

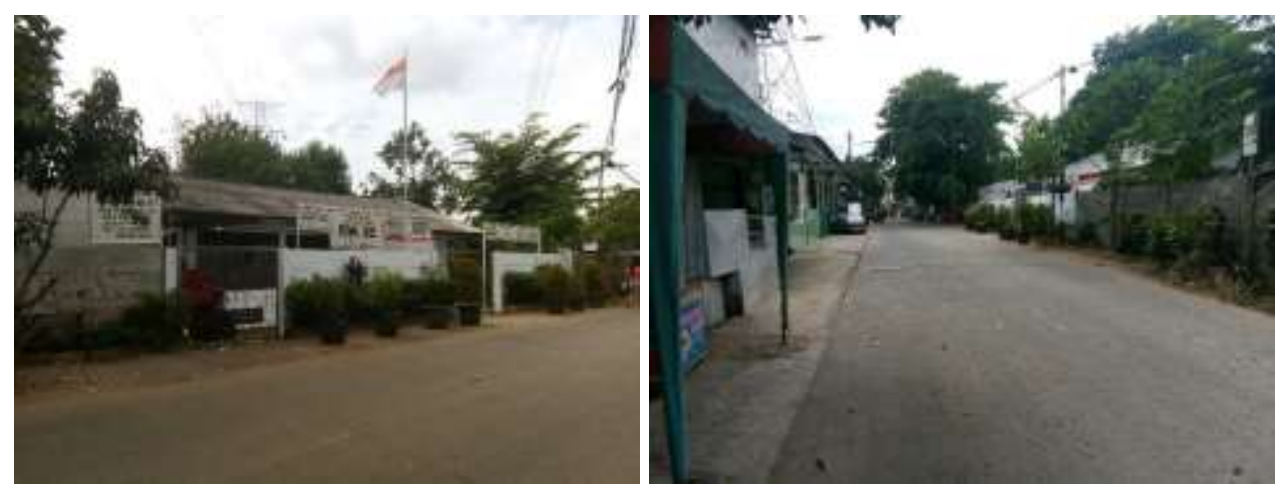

Gambar 4. Kantor RW 05

Kantor RW ini mulai beroperasional dari hari Senin sampai Jumat pada malam hari. Pada pagi sampai sore hari kantor ini tidak digunakan. Bangunan memiliki halaman yang cukup kecil dan memiliki pagar sehingga tidak mudah diakses oleh warganya. Apalagi pada pagi hingga sore hari ini kantor ini tidak beroperasional dan pagar ditutup.

Kekosongan kantor ini dikarenakan kepala RW dan beberapa staf yang memiliki pekerjaan utama diluar dari kantor RW sehingga justru pada saat pagi hingga sore hari kantor ini tidak terlihat berfungsi sebagaimana kantor lazimnya.

\section{Penggunaan Kantor RW 08}

Kantor RW 08 terletak di Jalan Halim Perdanakusuma. Akses menuju kantor ini sebenarnya merupakan jalan utama yang terdiri dari 2 jalur yang dipisahkan oleh penghijauan yang merupakan akses menuju Bandara Halim Perdanakusuma. Namun bangunan tertutup oleh bangunan liar dan tempat penyimpanan perlengkapan petugas kebersihan lingkungan sehingga tidak terlihat dari jalan utama tersebut. Akses menuju kantor ini justru melalui jalan kecil yang cukup sulit dijangkau oleh kendaraan roda empat.
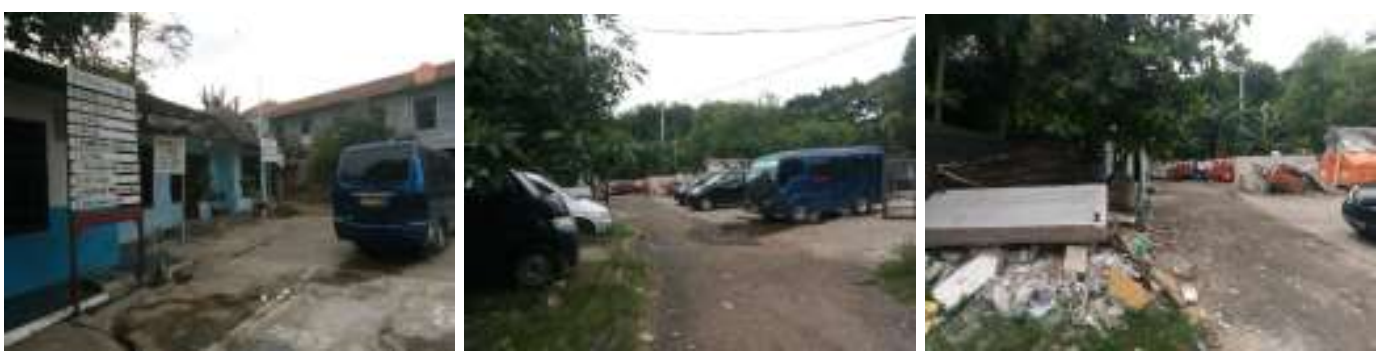

Gambar 5. Kantor RW 08

Kantor RW ini mulai beroperasional dari hari Senin sampai Jumat pada malam hari. Pada pagi sampai sore hari kantor ini tidak digunakan. Bangunan memiliki halaman yang cukup kecil dan memiliki pagar sehingga tidak mudah diakses oleh warganya. Apalagi pada pagi hingga sore hari ini kantor ini tidak beroperasional dan pagar ditutup.

Kekosongan kantor ini dikarenakan kepala RW dan beberapa staf yang memiliki pekerjaan utama diluar dari kantor RW sehingga justru pada saat pagi hingga sore hari kantor ini tidak terlihat berfungsi sebagaimana kantor lazimnya.

\section{Penggunaan Kantor RW 09}

Kantor RW 09 terletak di Jalan Jengki yang merupakan jalan yang cukup ramai oleh masyarakat sekitar serta jalur lintas wilayah. Kantor ini dikelilingi oleh beberapa fungsi gedung lainnya, antara lain: SD Kebon Pala 03 Pagi, SD Kebon Pala 05 Pagi, Taman Pemakaman Umum, dan bisnis komunitas. 


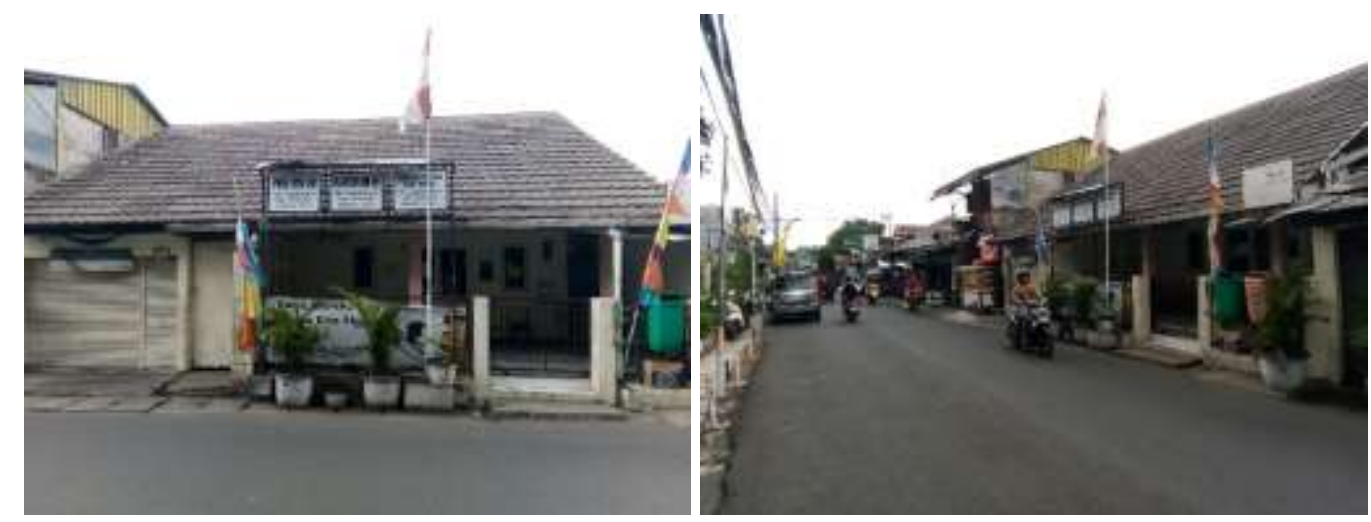

Gambar 6. Kantor RW 09

Kantor RW ini mulai beroperasi dari Senin hingga Jumat malam. Pagi hingga sore hari kantor ini tidak digunakan. Bangunan tersebut tidak memiliki pekarangan dan berpagar sehingga tidak mudah dijangkau oleh warganya. Apalagi pada pagi hingga sore ini kantor tidak beroperasi dan pagar ditutup.

Kekosongan kantor ini disebabkan oleh adanya ketua RW dan beberapa pegawai yang mempunyai pekerjaan utama di luar kantor RW sehingga pada pagi hingga sore hari kantor ini tampak tidak berfungsi seperti kantor biasanya.

Tidak banyak aktivitas warga yang terjadi di dalamnya. Hanya melayani urusan administrasi warga negara tanpa ada aktivitas publik.

\section{Kesimpulan}

Kantor RW yang berada pada Kelurahan Kebon Pala tidak berfungsi sebagaimana mestinya dan tidak mendukung program pemerintah. Hal ini disebabkan beberapa hal, diantaranya:

a. Pengurus yang memiliki pekerjaan utama diluar kantor RW itu sendiri sehingga justru pada saat jam kerja kantor RW ini sepi.

b. Pada beberapa kantor RW berada pada lokasi yang cukup sulit diakses sehingga tidak banyak warga yang bisa memafaatkan kantor ini.

c. Halaman kantor RW sebagai ruang publik tidak memiliki ukuran yang cukup luas sehingga tidak bisa digunakan warga untuk melakukan berbagai aktivitas bersama. Apalagi di beberapa kantor RW memiliki pagar dan terkunci sehingga tidak bebas diakses oleh masyarakat.

\section{Daftar Pustaka}

Carr, S., Francis, M., Rivlin, L. G., \& Stone, A. M. (1992). Public Space. New York: Cambridge University Press.

Gehl, J. (1987). Life Between Buildings: Using Public Space. New York: Van Nostrand Reinhold.

Hakim, R., \& Utomo, H. (2003). Komponen Perancangan Arsitektur Lansekap: Prinsip-Unsur dan Aplikasi Desain. Jakarta: Penerbit Bumi Aksara.

Hantono, D. (2017). Pengaruh Ruang Publik Terhadap Kualitas Visual Jalan Kali Besar Jakarta. Jurnal Arsitektura, 15(2), 532-540. https://doi.org/10.20961/arst.v15i2.15114

Hantono, D., \& Hakim, A. H. (2019). Identifikasi Elemen Fisik Ruang Publik yang Berpengaruh Terhadap Pembentukan Visual Kawasan Kota Tua Jakarta. Jurnal Emara, 5(2), 75-79. https://doi.org/10.29080/eija.v5i2.879

Hastona, I. (2015). Fungsi Pembinaan Lurah Terhadap Rukun Tetangga dan Rukun Warga di Kelurahan Tangkerang Tengah Kecamatan Marpoyan Damai Kota Pekanbaru Tahun 20132014. Jurnal Online Mahasiswa Fakultas IImu Sosial Dan IImu Politik Universitas Riau, 2(2), $1-15$.

Jodie, Y., Silitonga, S., \& Aritonang, E. (2019). Studi Pola Ruang Luar pada Kegiatan Budaya di Huta Siallagan. Jurnal Arsitektur Alur, 2(2). https://doi.org/10.17605/jalur.v2i2.528.g565

Krier, R. (1979). Urban Space. New York: Rizzoli.

Lang, J. (1987). The Built Environment Social Behavior: Architecture Determinism Rexamined Viair. Cambridge: The WIT Press.

Madanipour, A. (2003). Public and Private Spaces of the City. London: Routledge.

Prayitno, B. (2017). Co-habitation Space: A Model for Urban Informal Settlement Consolidation for the Heritage City of Yogyakarta, Indonesia. Journal of Asian Architecture and Building Engineering (JAABE), 16(3), 527-534. https://doi.org/10.3130/jaabe.16.527

Program Studi Arsitektur Universitas Katolik Santo Thomas ojs.ust.ac.id 51 
Jurnal Arsitektur AIJR - Vol 3 No 2 September 2020

e-ISSN 2685-1490; p-ISSN 2615-1472

Santoso, J. T., Mustikawati, T., Suryasari, N., \& Titisari, E. Y. (2016). Pola Aktivitas Wisata Belanja dI Kampung Wisata Keramik Dinoyo, Malang. Tesa Arsitektur, 14(1), 1. https://doi.org/10.24167/tes.v14i1.560

Setyowati, S., Djunaedi, A., Pramitasari, D., \& Sarwadi, A. (2020). The Impact of the Characteristics of Riverbanks Settlements on the Sustainability of Kali Pepe Surakarta. In IOP Conference Series: Earth and Environmental Science (pp. 1-10). IOP Publishing. https://doi.org/10.1088/1755-1315/447/1/012054

Shirvani, H. (1985). The Urban Design Process. New York: Van Nostrand Reinhold Company.

Silitonga, S., \& Naibaho, P. D. R. (2019). Fenomena Rumah Sederhana di Kota Medan. Jurnal Arsitektur Alur, 2(1). https://doi.org/10.17605/jalur.v2i1.369 